Рекомендованад. біол. наук, проф. Л. С. Фірою

уДК 615.014/.015.45-06:616.36-002-099

\title{
ДОСЛІДЖЕННЯ ГОСТРОЇ ТОКСИЧНОСТІ СУХОГО ЕКСТРАКТУ З ЛИСТЯ АБРИКОСА ЗВИЧАЙНОГО
}

\author{
СА. Л. Штробля \\ ДВНЗ “Ужгородський національний університет”
}

\begin{abstract}
Резюме: в експерименті на щурах обох статей проведено вивчення гострої токсичності сухого екстракту 3 листя абрикоса. Встановлено, що введення екстракту в організм тварин у дозі 5000 мг/кг маси тіла не викликало ознак інтоксикації та загибелі тварин, що дозволило віднести його до VI класу токсичності - нешкідливі речовини.

Ключові слова: гостра токсичність, щури, сухий екстракт з листя абрикоса, клас токсичності.
\end{abstract}

Вступ. Актуальними завданнями сучасної фармації $€$ пошук рослин з достатньою сировинною базою, раціональне та комплексне використання сировини, а також створення на їх основі нових лікарських засобів. Попит на лікарські препарати рослинного походження протягом останнього десятиріччя зростає. Це зумовлено насамперед безліччю переваг фітопрепаратів перед синтетичними лікарськими засобами та багатовекторністю їх застосування [1, $2,3]$. Збільшення попиту на фітозасоби спонукає науковців та виробників до розширення номенклатури лікарських засобів рослинного походження і пошуку нових джерел рослинних субстанцій. 3 огляду на вищезазначене актуальним є питання пошуку вітчизняних рослинних джерел фітозасобів з достатньою сировинною базою. Сучасними підходами до вирішення цієї проблеми може бути як вивчення та введення в медичну практику нових лікарських рослин, так і дослідження та впровадження у виробництво інших видів сировини вже відомих рослин, що сприятиме більш раціональному використанню рослинних ресурсів, підвищить рентабельність виробництва і зможе його здешевити [8, 9].

Такою рослиною, що здавна використовується в офіцинальній, народній медицині та лікувальному харчуванні, є абрикос звичайний (Armeniaca vulgaris Lam.). Завдяки хімічному складу плодів, насіння, листя та інших органів абрикоса $[4,5]$, його використовують при різноманітних захворюваннях та створюють на основі БАР лікарські засоби.

При дослідженні нового лікарського засобу обов'язковою характеристикою є визначення показника ЛД (середньолетальна доза) як критерію гострої токсичності препарату [7]. Це дозволяє оцінити ступінь його безпечності, широту терапевтичної дії і нешкідливість в умовах застосування в дозах, які в сотні разів перевищують терапевтичну.
Методи дослідження. 3 метою визначення ЛД 50 гостру токсичність сухого екстракту з листя абрикоса звичайного вивчали відповідно до методичних рекомендацій ДФЦ МОЗ України [7] на білих щурах обох статей за умов його одноразового внутрішньошлункового введення. Згідно з методичними рекомендаціями ДФЦ МО3 України при виборі доз для внутрішньошлункового введення критерієм гострої токсичності є максимальна доза четвертого класу токсичності (малотоксичні речовини) - 5000 мг/кг. Якщо при цьому не спостерігається загибель тварин, введення більшої дози недоцільне.

Зважаючи на вищенаведене, нами була обрана доза сухого екстракту 5000 мг/кг, яку вводили внутрішньошлунково щурам самцям та самкам з масою тіла 180-200 г. Розчин для введення готували шляхом розведення 1 г екстракту в 5 мл води, який отримувала одна тварина. Після його введення за щурами спостерігали протягом 14 днів та оцінювали загальний стан тварин, летальність, динаміку маси тіла, після закінчення досліду після виведення тварин з експерименту проводили макроскопічну оцінку стану внутрішніх органів та розраховували їх масові коефіцієнти. Тварини були розділені на наступні групи:

- контроль, яким вводили еквівалентну кількість питної води;

- тварини, яким вводили сухий екстракт з листя абрикоса звичайного.

Результати й обговорення. Після внутрішньошлункового введення екстракту з листя абрикоса звичайного в дозі 5000 мг/кг ознак інтоксикації у щурів обох статей не виявлено: тварини були активними, реагували на звукові і світлові подразники, процеси сечовиділення були в нормі, порушення дихання та судом не спостерігали. Рефлекторна збудливість у всіх тварин була збережена. У всіх дослідних щурів спожи-

ISSN 2312-0967. Pharmaceutical review. 2015. № 1 
Фармакологічні дослідження біологічно активних речовин Pharmacological researches of biologically active substances вання води та їжі не відрізнялось від інтактних тварин. Загибелі тварин протягом всього періоду спостереження не зареєстровано (табл. 1).

Для оцінки токсичного впливу сухого екстракту з листя абрикоса на організм проводили дослідження динаміки маси тіла тварин. В результаті проведених досліджень встановлено, що у щурів після внутрішньошлункового введення даної лікарської форми та у інтактних тварин протягом терміну спостереження відбувається збільшення маси тіла (табл. 2).

Через 14 діб після закінчення експерименту тварин піддавали евтаназії під тіопенталовим наркозом. Проведено макроскопічний огляд внутрішніх органів. Під час розтину всі тварини

мали незмінений шерстний покрив та слизові оболонки природних отворів. Поверхня печінки, нирок та надниркових залоз гладенька. Колір, форма та розмір всіх органів звичайний. Підшлункова залоза сірувато-рожевого кольору гілко-тяжистого вигляду. На слизовій оболонці шлунка чітко виражений рельєф складок. Слизова оболонка кишечника не змінена. В грудній порожнині всі органи розташовані анатомічно правильно. М'яз серця на розрізі темно-червоний, легені насичені повітрям, листки плеври не змінені.

При вивченні масових коефіцієнтів внутрішніх органів змін не виявлено. Результати їх дослідження наведено в таблицях 3, 4.

Таблиця 1. Дослідження гострої токсичності сухого екстракту з листя абрикоса звичайного при одноразовому внутрішньошлунковому введенні білим щурам обох статей

\begin{tabular}{|c|c|c|c|}
\hline \multirow{2}{*}{ Групи тварин } & \multirow{2}{*}{$\begin{array}{c}\text { Доза, } \\
\text { мл }\end{array}$} & $\begin{array}{c}\text { Самці } \\
\text { кільсть загиблих тварин/загальна } \\
\text { кількь тварин у групі }\end{array}$ & $\begin{array}{c}\text { кількість загиблих тварин/загальна } \\
\text { кількість тварин у групі }\end{array}$ \\
\hline Контроль, питна вода & 5,0 & $0 / 6$ & $0 / 6$ \\
\hline $\begin{array}{c}\text { Сухий екстракт із листя } \\
\text { абрикоса }\end{array}$ & 5,0 & $0 / 6$ & $0 / 6$ \\
\hline
\end{tabular}

Таблиця 2. Рандомізація щурів після одноразового внутрішньошлункового введення сухого екстракту 3 листя абрикоса звичайного

\begin{tabular}{|c|c|c|c|c|}
\hline Умови досліду & Вихідні дані & 3 дні, г & 7 днів, г & 14 днів, г \\
\hline \multicolumn{5}{|c|}{ самці } \\
\hline Контроль, питна вода & $190,30 \pm 6,10$ & $192,00 \pm 7,12$ & $192,70 \pm 5,60$ & $198,75 \pm 5,40$ \\
\hline $\begin{array}{c}\text { Сухий екстракт з листя } \\
\text { абрикоса }\end{array}$ & $193,20 \pm 6,22$ & $195,70 \pm 6,45$ & $198,05 \pm 5,35$ & $202,30 \pm 5,65$ \\
\hline \multicolumn{5}{|c|}{ самки } \\
\hline Контроль, питна вода & $192,00 \pm 4,25$ & $193,50 \pm 5,35$ & $196,20 \pm 6,45$ & $200,3 \pm 4,62$ \\
\hline $\begin{array}{c}\text { Сухий екстракт з листя } \\
\text { абрикоса }\end{array}$ & $193,50 \pm 5,15$ & $194,30 \pm 4,45$ & $197,50 \pm 6,13$ & $203,70 \pm 4,95$ \\
\hline
\end{tabular}

Примітка. * - достовірне відхилення щодо вихідних даних, $\mathrm{p} \leq 0,05$.

Таблиця 3. Масові коефіцієнти внутрішніх органів щурів-самців після одноразового внутрішньошлункового введення сухого екстракту з листя абрикоса звичайного

\begin{tabular}{|c|c|c|c|}
\hline \multirow{2}{*}{ Орган } & \multicolumn{2}{|c|}{ Умови досліду } \\
\cline { 2 - 4 } & Контроль, питна вода & Сухий екстракт з листя абрикоса \\
\hline \multicolumn{2}{|c|}{ Печінка } & $5,15 \pm 0,17$ & $5,30 \pm 0,16$ \\
\hline \multirow{2}{*}{ Нирки } & права & $0,42 \pm 0,03$ & $0,43 \pm 0,02$ \\
\cline { 2 - 4 } & ліва & $0,43 \pm 0,02$ & $0,43 \pm 0,01$ \\
\hline \multicolumn{2}{|c|}{ Серце } & $0,40 \pm 0,03$ & $0,42 \pm 0,02$ \\
\hline \multicolumn{2}{|c|}{ Легені } & $0,80 \pm 0,02$ & $0,80 \pm 0,01$ \\
\hline \multicolumn{2}{|c|}{ Селезінка } & $0,60 \pm 0,02$ & $0,59 \pm 0,01$ \\
\hline \multicolumn{2}{|c|}{ Надниркові залози } & $0,030 \pm 0,001$ & $0,031 \pm 0,002$ \\
\hline \multicolumn{2}{|c|}{ Тимус } & $0,15 \pm 0,01$ & $0,13 \pm 0,02$ \\
\hline \multirow{2}{*}{ Сім'яники } & правий & $0,68 \pm 0,02$ & $0,67 \pm 0,03$ \\
\cline { 2 - 4 } & лівий & $0,67 \pm 0,01$ & $0,67 \pm 0,02$ \\
\hline
\end{tabular}

Примітка. * - достовірне відхилення щодо вихідних даних, $\mathrm{p} \leq 0,05$. 
Фармакологічні дослідження біологічно активних речовин

Pharmacological researches of biologically active substances

Таблиця 4. Масові коефіцієнти внутрішніх органів щурів-самок після одноразового внутрішньошлункового введення сухого екстракту з листя абрикоса звичайного

\begin{tabular}{|c|c|c|c|}
\hline \multirow{2}{*}{\multicolumn{2}{|c|}{ Орган }} & \multicolumn{2}{|c|}{ Умови досліду } \\
\hline & & Контроль, питна вода & Сухий екстракт з листя абрикоса \\
\hline \multicolumn{2}{|c|}{ Печінка } & $4,75 \pm 0,15$ & $4,76 \pm 0,12$ \\
\hline \multirow{2}{*}{ Нирки } & права & $0,43 \pm 0,03$ & $0,45 \pm 0,02$ \\
\hline & ліва & $0,43 \pm 0,03$ & $0,43 \pm 0,03$ \\
\hline \multicolumn{2}{|c|}{ Серце } & $0,42 \pm 0,02$ & $0,42 \pm 0,03$ \\
\hline \multicolumn{2}{|c|}{ Легені } & $0,78 \pm 0,03$ & $0,79 \pm 0,03$ \\
\hline \multicolumn{2}{|c|}{ Селезінка } & $0,56 \pm 0,02$ & $0,54 \pm 0,02$ \\
\hline \multicolumn{2}{|c|}{ Надниркові залози } & $0,032 \pm 0,002$ & $0,032 \pm 0,002$ \\
\hline \multicolumn{2}{|c|}{ Тимус } & $0,13 \pm 0,009$ & $0,14 \pm 0,012$ \\
\hline
\end{tabular}

Примітка. * - достовірне відхилення щодо вихідних даних, $\mathrm{p} \leq 0,05$.

При аналізі внутрішніх органів щурів-самців відмічено незначне збільшення маси печінки та серця, хоча ці зміни не були вірогідними. Маса нирок, легень та сім'яників залишалась на вихідному рівні. Дещо зменшилась маса селезінки та тимуса, але це зменшення було дуже незначним і практично можна вважати, що змін внутрішні органи самців не зазнали після введення їм сухого екстракту з листя абрикоса.

У щурів-самок після отримання сухого екстракту з листя абрикоса незначно збільшились печінка, легені та тимус. Маса селезінки у цій дослідній групі зменшилась на 0,02 г. Вірогідних змін у масових коефіцінтах органів самок,

\section{Література}

1. Колесова В. Г. Антиоксидантная терапия растениями / В. Г. Колесова, В.А.Дадали, В.И.Дойко [и др.] // Эфферент. терапия. - 1996. - № 1. - С. 67-70.

2. Лекарственные растения : самая полная энциклопедия / [Лебеда А. Ф., Джуренко Н. И., Исайкина А. П. и др.]. - Москва : АСТ-ПРЕСС КНИГА, 2004. - 912 с.

3. Липкан Г. Н. Витаминные растения в медицине / Г. Н. Липкан. - Киев, 2006. - 628 с.

4. Липкан Г. Н. Применение плодово-ягодных растений в медицине / Г.Н.Липкан. - Киев, 2006. - 444 с. 5. Липкан Г. Н. Растения в медицине : 15-томная энциклопедия / Г. Н. Липкан. - К., 2008. - Том 2. 415 c.

6. Сидоров К. К. О классификации токсичности ядов які отримували екстракт порівняно з інтактними тваринами, не зареєстровано.

Таким чином, проведені дослідження з вивчення гострої токсичності сухого екстракту з листя абрикоса звичайного підтвердили відсутність його токсичної дії при одноразовому внутрішньошлунковому введенні щурам в дозі 5000 мг/кг.

Висновок. Встановлено, що ЛД ракту з листя абрикоса звичайного знаходиться понад 5000 мг/кг. Згідно з токсикологічною класифікацією речовин К. К. Сидорова [6], сухий екстракт з листя абрикоса звичайного при внутрішньошлунковому введенні належить до VI класу токсичності - нешкідливі речовини.

при парентеральных способах введения / К. К. Сидоров // Токсикология новых промышленных химических веществ : сборник статей / под ред. А. А. Летавета [и др.] - М. : Медгиз, 1973. - Вып. 13. - С. 47-57.

7. Стефанов О. В. Доклінічні дослідження лікарських засобів ; за ред. О. В. Стефанова. - К. : ВД «Авіцена», 2001. - 528 c.

8. Pengelly A. The constituents of medicinal plants. An introduction to the chemistry and therapeutics of herbal medicines / A. Pengelly - 2-nd ed. Wallingford : CABI Publishing, 2004. - $184 \mathrm{p}$.

9. Wichtl M. Herbal Drugs and Phytopharmaceuticals. A Handboo for Practice on a Scientific Basis / M. Wichtl Stuttgart : medpharm GmbH, 2004. - P. 274-277.

ISSN 2312-0967. Pharmaceutical review. 2015. № 1 
Фармакологічні дослідження біологічно активних речовин

Pharmacological researches of biologically active substances

ИССЛЕДОВАНИЕ ОСТРОЙ ТОКСИЧНОСТИ СУХОГО ЭКСТРАКТА ИЗ ЛИСТЬЕВ АБРИКОСА ОБЫКНОВЕННОГО

\section{А. Л. Штробля}

ГВУЗ “Ужгородский национальный университет”

Резюме: в эксперименте на крысах обоих полов проведено изучение острой токсичности сухого экстракты из листьев абрикоса. Установлено, что введение экстракта в организм животных в дозе 5000 мг/кг не вызывало признаков интоксикации и гибели животных, что разрешило отнести его к классу токсичности - безвредные вещества.

Ключевые слова: острая токсичность, крысы, сухой экстракт из листьев абрикоса, класс токсичности.

RESEARCH OF ACUTE TOXICITY OF DRY EXTRACT FROM LEAVES OF APRICOT USUAL

\section{A. L. Stroblia}

SHEl "Uzhhorod National University"

Summary: in experiment on rats of both sexes studied the acute toxicity of dry extract of the leaves of apricot. The introduction of the extract to animals at a dose of $5000 \mathrm{mg} / \mathrm{kg}$ did not cause signs of intoxication and death of animals allowed to take it to class VI of toxicity class.

Key words: acute toxicity, rats, dry extract of leaves of apricot, toxicity class.

Отримано 11.03.2015

ISSN 2312-0967. Фармацевтичний часопис. 2015. № 1 